\title{
The Establishment of the School of Virtual Education at the University of Dodoma in Tanzania: Personal Experience and Reflections
}

\author{
Justinian Anatory \\ School of Informatics \\ The University of Dodoma, \\ Dodoma, Tanzania
}

\begin{abstract}
This paper describes the personal experience and reflections of the author who was the first Dean of the School of Virtual Education (SoVE) at the University of Dodoma (UDOM) in Tanzania. It describes in detail different tactics the author used to establish SoVE. In additional, it is suggested that the best way to implement a vibrant SoVE in developing countries like Tanzania can include three departments namely Department of Content Engineering and Multimedia Technology (DoCEMT), Department of Virtual Educational Technologies and Applications (DoVETA) and Department of Virtual Education Delivery (DoVED). The first two Departments are for capacity building while the third is for technology enhanced teaching and learning, online teaching and learning and instructional design for virtual delivery.
\end{abstract}

\section{General Terms}

School of Virtual Education, ICT for Education, E-learning

\section{Keywords}

virtual education, learning management system, ICT, School of virtual education, Content Engineering, Animation Technology, Educational Technologies, Virtual Education delivery, technology enhanced teaching and learning.

\section{INTRODUCTION}

The University of Dodoma (UDOM)[1] was established as a public university located in the vicinity of Dodoma municipality[2]. It was established on the 28th March, 2007 using the Universities Act No. 7 of 2005 and the Universities Regulations 2007 and its operations guided by the University of Dodoma Charter 2007[3]. UDOM initially started with four schools, namely School of Education, School of Humanities, School of Social Sciences and School of Informatics [1]. Generally, the University has been designed on a campus college mode each of which is semi-autonomous. In its structure, there are six Colleges. These are College of Education (CoED), College of Humanities and Social Sciences (CoHSS) and College of Informatics and Virtual Education (CIVE). Other Colleges include College of Natural and Mathematical Sciences (CNMS), College of Health Sciences (CoHS) and College of Earth Sciences (CoES) [1]. The total number of students expected at the Campus is 40,000 . This number is equal to total number of student population enrolled at all public and private Higher learning institutions in Tanzania.

The rationale for the establishment of UDOM was that, the number of university student population in Tanzania is relatively low compared to that in the neighboring countries (Uganda and Kenya). With the emerging East African Community common labour market (formal and informal)
Tanzania will be losing out to its neighbours. This situation can result in instability of the community as was the case in the late seventies. Effort to redress the situation was necessary. On the other hand, the Government of Tanzania had introduced universal primary education making it mandatory for all children to enroll for primary school education. The result was massive expansion of primary school student enrollment, which increased the number of students seeking places in secondary schools. The government responded by increasing secondary schools enrollment. The spinoff effect of that increase is the significant increase in the number of young people seeking for higher education. In addition, it is believed as the father of the nation Mwalimu Julius Kambarage Nyerere [4] the first president of United Republic of Tanzania said in one of his speeches that the most effective way to help the nation eradicate poverty is to educate its citizens.

The response to the need and demand for higher education coupled with liberalization of the sector saw the number of private universities coming up every other day in different parts of the country. However, the private universities cannot solve the problem of quest for higher education for majority of Tanzanians because the fees and related costs are prohibitive. The enrollment capabilities are very low compared to demand. The Government therefore decided to came in and establish a university with large enrollment capacity choosing Dodoma for that. The choice is ideal, Dodoma being the capital and in the centre of the country and accessible to students by road from different parts of the country [2].

CIVE is among the first three Colleges of the University of Dodoma that started its operation in 2008 with two Schools. The School of Informatics was among of the first school to be established in 2007. The School of Virtual Education was established in 2008. The primary function of establishment of SoVE was to deliver programs offered by different academic units at UDOM in a virtual environment within and beyond UDOM campus and build capacity in virtual education. It was expected that the operationalization of SoVE will enable UDOM to reach more citizens and increase enrolment. Although many efforts were made, it was very difficult to realize the goal. This paper is analyzing the tactics and challenges went through to realize SoVE at UDOM. The paper is organized in six sections. Section one is introducing the matter while section two is elaborating SoVE since its establishment in 2008. Section three describes the challenges of structure in 2008 and the trends of its establishment are elaborated in section four. Section five is describing the current implementations which include different departments, 
proposed programmes and roles of each department and recommendations and conclusion is given in section six.

\section{ESTABLISHMENT OF THE SCHOOL OF VIRTUAL EDUCATION IN 2008}

SoVE is the second School to be established in CIVE. It was established in 2008. The primary function of the school is to deliver virtual education/online programmes within and beyond the university campus and build capacity in virtual education in Tanzania and beyond. Morever SoVE will facilitate the same from other academic units within the university. To do this effectively and efficiently the school has to:

- Build capacity in virtual education delivery within UDOM and beyond.

- Administer research and consultancy in virtual education and manage virtual Education delivery

- Provide appropriate platform and learning management system (LMS) that are continuously improved and updated through research and development.

- Provide secure delivery and content where security features are improved over time to cub new threats.Provide and manage infrastructure to develop, store and distribute programmes.
- Manage and store generated and developed knowledge to ensure that there is no loss in effort and competences developed or unnecessary duplication of efforts.

- Coordinate content preparation and package them in a manner that enables effective self learning.

- Ensure that content delivery is professionally done.

- Deliver courses using appropriate pedagogica strategies and technologies in enhancing access to relevant, affordable, cost effective and flexible education and training.

- Provide training and consultative services towards development of e-Learning skills and competencies.

- Promote and coordinate collaborative research and development of e-Learning tools and technologies.

- Provide courses of high quality on a range of subjects capitalizing on the considerable expertise and prestige of educational institutions in the region.

To perform these functions and others relevant to the school and the university it was proposed the school to be organized into six basic functional and administrative units shown in Fig. 1.

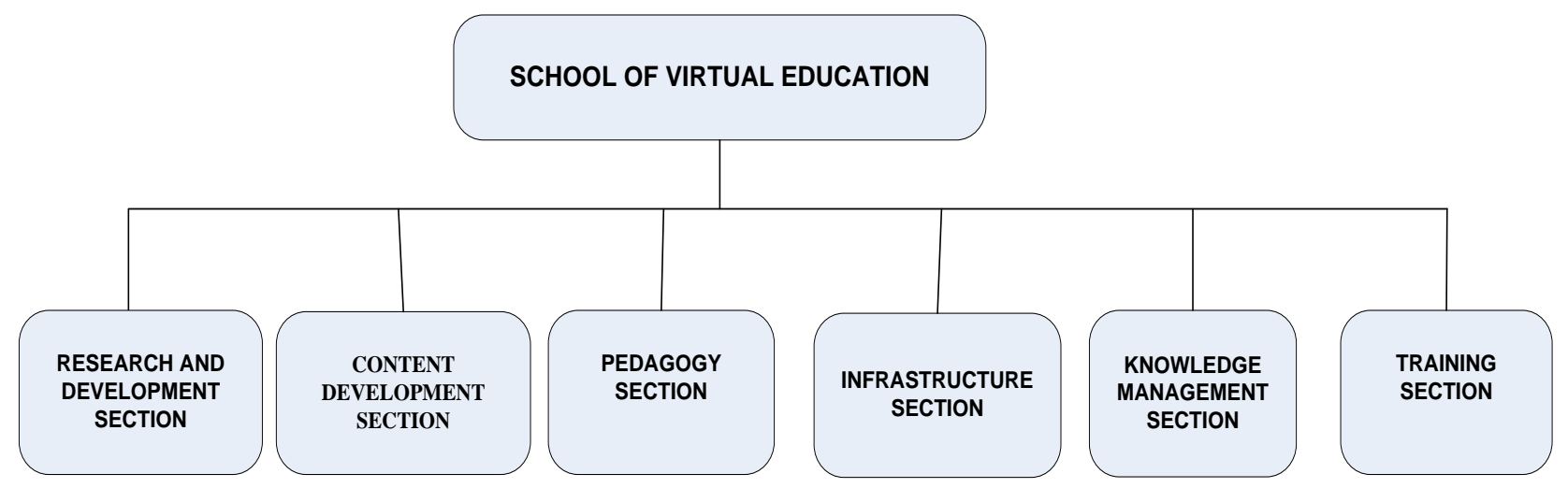

Fig. 1: School of Virtual Education structure proposed in 2008

\subsection{The Research and Development Section}

It was proposed that virtual education delivery is very dynamic and is always changing as the Information and Communication Technology (ICT) itself is changing rapidly. Therefore the section of research and development was proposed. Also the section was responsible to determine marketable courses through careful planning from informed point of view. If UDOM is to have a foot prints in the delivery of virtual education it will have to develop new systems and carryout research in all areas related to it. The areas proposed for research include platforms to deliver virtual education courses, virtual education infrastructures, learning management systems, security of delivery education, content ownership, marketing etc. To perform these functions effectively, it was proposed that the section be organized into four administrative sub-sections shown in fig. 2 with each sub section be assigned different activities as mention above.

\subsection{The Content Development Section}

It was proposed that delivery of virtual education need content to be prepared appropriately for the various programmes to be offered. The role of this section was to coordinate and to oversee the preparation of contents and to ensure appropriateness of such contents for the intended purpose. To perform these functions effectively, it was proposed that the section be organized into six administrative sub-sections shown in Fig. 3.

\subsection{The Pedagogy Section}

In collaboration with appropriate sections in the content development and training sections shall ensure that the delivery of content is consistent with teaching. To perform this function effectively, it is being proposed that the Section be organized into two administrative sub-sections as shown in Fig. 4. 


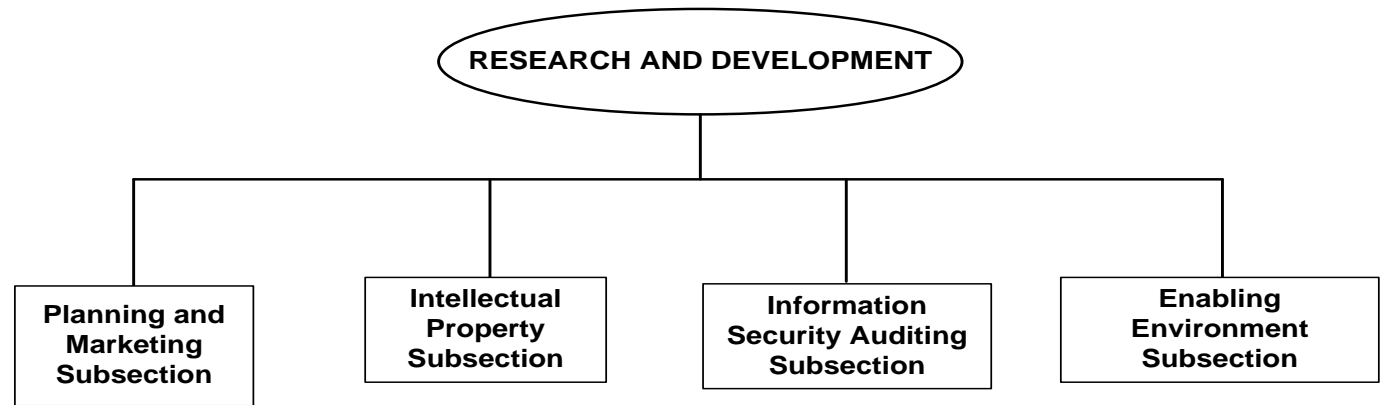

Fig. 2: The structure of Planning and Research section proposed in 2008

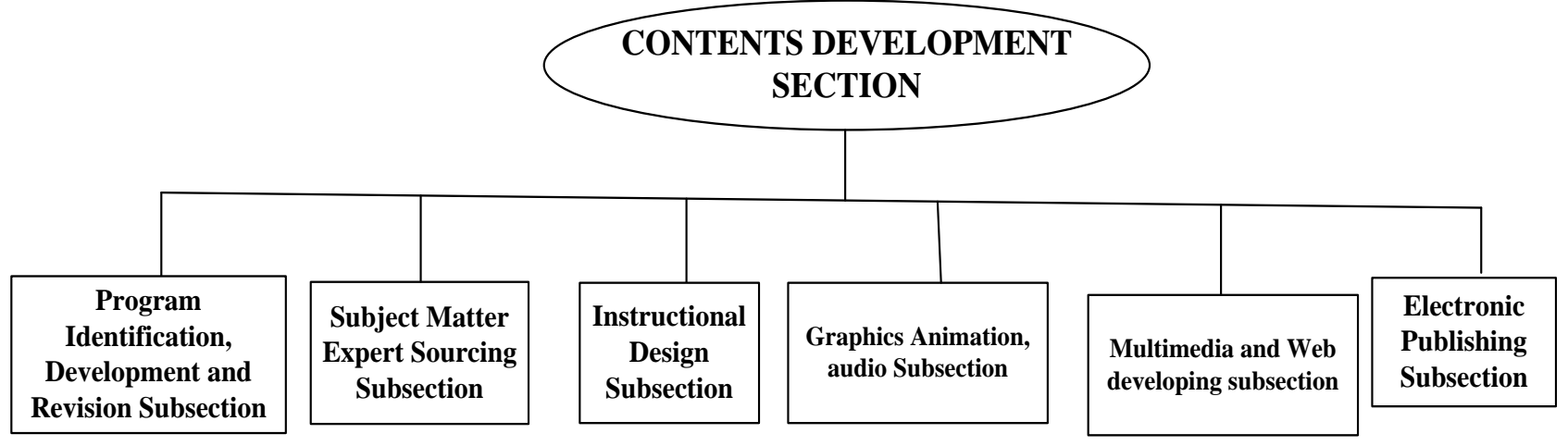

Fig.3: The structure of the Content Development section proposed in 2008

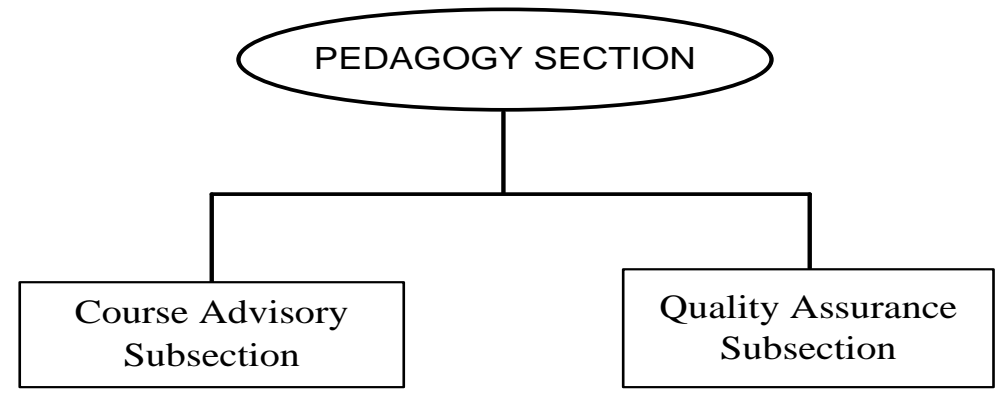

Fig. 4: The structure of Pedagogy section proposed in 2008

\subsection{The Infrastructure Section}

To develop courseware for different programmes which is appropriate for delivery through multimedia systems needs a combination of different facilities. These include simulators, platforms, network systems, laboratory equipment, etc. In addition, all equipment, software and networks need to be maintained. For this purpose engineering subsection was proposed. This role was assigned to infrastructure section as shown in Fig. 5.

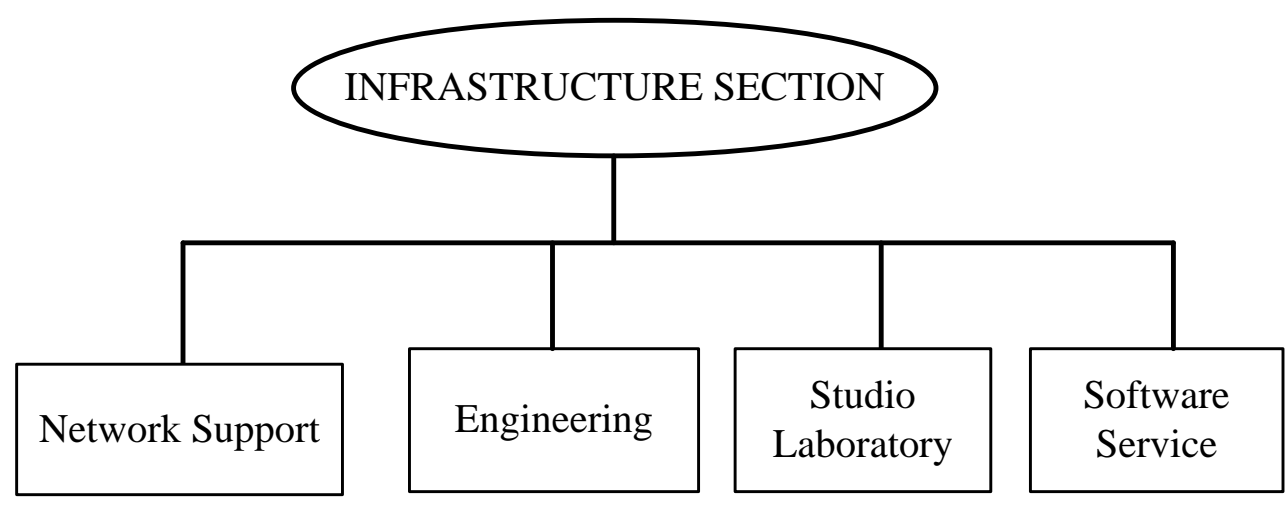

Fig. 5: The structure of Infrastructure section proposed in 2008 


\subsection{The Knowledge Management Section}

Virtual education activities like many other academic activities at UDOM shall generate resources, content and new knowledge. These have to be properly stored, managed and controlled while ensuring that they are conveniently accessible all the time to the intended audience. This is meant to ensure that there is no unnecessary duplication of effort at UDOM in its endeavor to excel in ICT and other fields. The Knowledge Management section was assigned to manage content, coordinate the storage and distribute to the training section.

\subsection{The Training Section}

Training is the main activity, i.e. the principle output for the school. It is to different programmes offered at University using multimedia technologies where space and time shall not be a constraint. The delivery shall involve registration, management and monitoring continuously the students. Therefore, a delivery platform is required. The same applies to the Learning Management System (LMS). There must be content to be delivered and it has to be in a manner and form that shall facilitate effective self-learning. The security of content and its delivery are important for developers and for the school. Therefore, there must be other administrative units to support the training function. To perform these functions effectively, it is being proposed that the section be organized into five administrative sub-sections shown in Fig. 6. It was proposed to start the sub-sections as sections and those that shall grow in terms of activities to be transformed to sections. The proposed sub-sections are Programmes and e-schools management, Finance Management, Academic Affairs, Student administration and Management and Learner Support and Management.

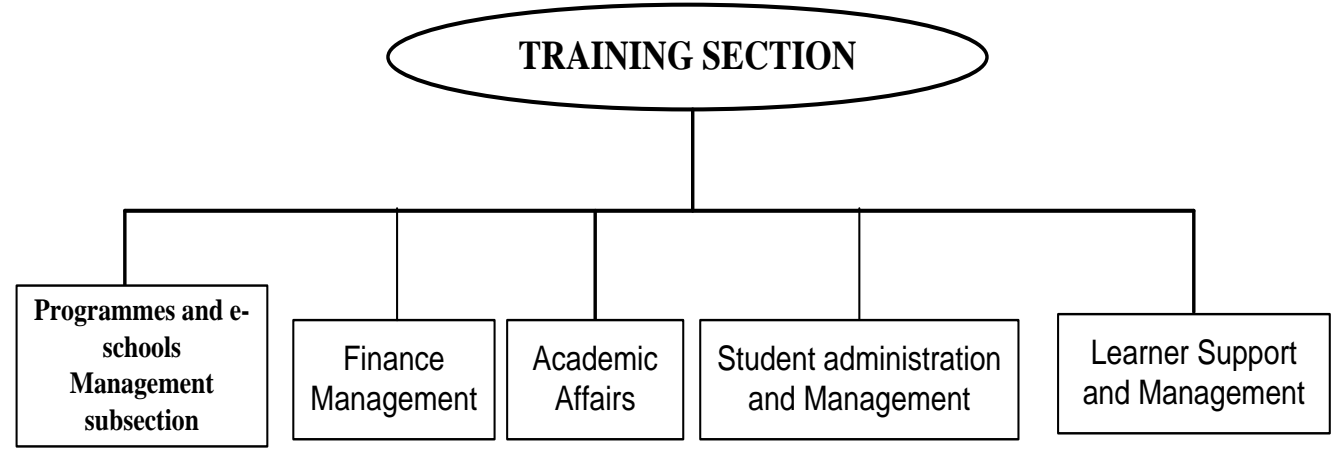

Fig. 6: The structure of the training section proposed in 2008

\section{CHALLENGES OF IMPLEMENTING SCHOOL STRUCTURE OF 2008}

During the implementations of the structure proposed in Fig.1, the school faced a number of challenges namely, lack of appropriate human resources to manage different subsections, lack of equipment in various section, lack of LMS, lack of policy and procedure, lack of regulations and rules, lack of knowledgeable academic staff with knowledge in virtual education. Other issues were unawareness of such technology among of staff in other university colleges, lack of connectivity, lack of content developers and multimedia experts. These factors lead to propose three sections in 2009 in the school which can be upgraded to department in the future for easily building capacity in virtual education and online delivery. These sections were Virtual Delivery (VD), Facilitation Capacity Building (FB) and Content Development (CD). Different proposed sections under SoVE structure in Fig. 1 were under virtual delivery section. Other two sections were for capacity building. FB and CD sections established two programmes for face to face in 2010.

\section{TRENDS IN THE ESTABLISHMENT OF THE SCHOOL OF VIRTUAL EDUCATION AFTER 2009}

The initial effort involved preparation of the School structure and basic requirements which was approved by UDOM in 2009. SoVE started up with the Dean only until March 2010 when ten (10) other staff were recruited. In order for SoVE to be operational, all requirements were delineated in 2009 . These included equipment, software and staff. The nature of the school necessitated for formulation of the ICT Policy and procedure, Virtual Education policy and Regulations. The draft of ICT Policy and procedure was finalized in 2009 and was approved by the University in March 2012[5]. The Virtual Education policy and Regulations document drafted in January 2011 and was approved in 2013[6]. The document enabled operations of the school by delineating, among other things, content development procedures, online program approval procedures, incentives, and use of online systems. Until these issues were resolved, the School was hardly become operational. It is in the meantime the school concentrated in building staff capacity and LMS.

LMS was designed and implemented in 2013. This enabled lecturers to interact with students online. Materials can be accessed virtually. The online manual for staff and students on how to download and upload materials is available at UDOM website in 2013[1]. Training of staff was conducted on January, 2012. Modalities for training staff from other colleges were finalized after having received expression of interest from some of them.

The school invited UDOM colleges to propose programmes to go online in 2010 and remind them on several occasions with visits to some College Principals on the issue. Response from principals was below expectations. The matter was presented in various meetings without success. The school observed that there was a huge gap between the school and other colleges regarding the understanding of virtual education. For example, when the SoVE was waiting for response from colleges, the SoVE chose to start with two programmes namely; Postgraduate Diploma in Education (PGDE) and Master in Business Administration (MBA). Content development started with academic staff in the College of 
Education in collaboration with staff in SoVE for PGDE programme. From this four issues emerged as follows:

- It was observed that ownership of programme by respective colleges was a fundamental.

- Content development by experts was a problem.

- Competence of our staff in virtual education was a problem.

- $\quad$ Some staff demanded that either content developed to be regarded as writing a book and be included in the academic staff promotion criterion or incentive scheme should be created.

- Unawareness of such programmes among UDOM staff.

Regarding the issue of ownership it was resolved that colleges should understand that SoVE was a coordination unit, and that it was providing a technical support. However, it was resolved that content and online programmes will remain as a property of respective colleges and this issue to be incorporated in the virtual education policy and its regulations.

To improve the competence of our staff the Bachelor of Science in Virtual Education (B.Sc. VE) was designed and offered for the first time in the academic year 2010/2011 for capacity building purposes [10]. This was also to enable staff that most of them were from BSc. in Computer Science and BSc. in Telecommunications Engineering to get an experience in virtual education. The BSc. in VE degree programme attracted three students. However, other students from College of Education especially Bachelor of Education with ICT (BED-ICT) were taking some courses from SoVE. This makes University to allow this programme to be conducted.

In 2011, the BSc. in VE programme was split into 3 degree programmes in order to make it more attractive. Resultant programmes included Bachelor of Science in Multimedia Technology and Animation (B.Sc. MTA), Bachelor of Science in ICT Mediated Content Development (B.Sc. ICT MCD) and Bachelor of Science in Online Teaching and Learning (B.Sc. OTL). Twelve students were attracted to these two programmes (6 in B.Sc. MTA and other 6 in B.Sc. ICT - MCD). The B.Sc. OTL degree programme was postponed for a reason that it would fall under the universitywide curricula review which was scheduled for 2012 .

The school noted that there were a number of graduates (first degree holders) at UDOM and Tanzania in general who would like to be players in virtual delivery but without background either in ICT or Education. For this matter the school developed a curriculum for Postgraduate Diploma in Education Technology (PGD ET) and Postgraduate Diploma in School Technology Integration, Coordination and Leadership (PGD STICL). The programmes were approved by university in 2011. Currently these are awaiting approval by Tanzania Commissions for Universities (TCU) [7].

The school noted that academic staff at UDOM (Assistant Lecturers, Lecturers, Senior Lecturers and Professors) including School Teachers (outside University) did not have background/knowledge in Virtual Education. To support these players in virtual delivery, the School developed a curriculum for Graduate Certificate in E-Learning and Online Teaching (GC EOT) and Graduate Certificate in School Technology Integration, Coordination and Leadership (GC STICL). The programmes were approved by relevant organs. These are yet to be offered awaiting approval by TCU. The programmes will run for short period in an executive mode for secondary school teachers, lecturers and instructors either on request or after identification of need by the school. The programmes is designed to be offered online for duration of 6 months and duration of 6 and 4 months for evening and regular modes respectively. This kind of programmes are available in most of Universities in developed countries such as USA, Canada, Malaysia, Australia etc. whereby online programmes are well developed and accepted.

Most of staff in the School of Virtual Education are junior staff and they do not have competence in virtual education. To enhance their new career, competencies in virtual delivery and capacity building for staff, the school established the Master of Education Technology Leadership (M.ETL) and the Master of Science in Education Technology (M.Sc. ET) were approved by university in 2011. The programmes await approval by TCU.

To build capacity for technical staff in content development, the school established a Diploma in Multimedia Technology (Dip. MT). The program is currently running. The programme is expected to increase enrolment catchment for its undergraduate programmes. Summary of all programmes proposed and which are running are as shown in Table 1,2 and 3. It can be observed that a number of students were in some programmes not stable. In summary a total of $51,73,16$ and 12 students are in first year, second year, and third year of study and graduated respectively. This makes a total of 140 students' enrolled in SoVE. Among of 12 students graduated with BSc. two students have been proposed to be employed by university as academician, while others will be employed as a technical staff. All student graduated in certificate programme are enrolled in Diploma programmes. In 2013, it was observed that the current structure does not respond to the functions of SoVE. It was proposed to restructure the school to respond to its new missions.

\section{CURRENT IMPLEMENTATION OF THE SCHOOL}

In 2013, after working in the school for more than three years in virtual delivery, the academic staff came with an opinion that there is a need to change naming of the departments to correspond to professional ready at respond to the new school functions. In 2014 the University of Dodoma approved the school to be organized into three departments namely Department of Content Engineering and Multimedia Technology (DoCEMT), Department of Virtual Educational Technologies and Applications (DoVETA) and Department of Virtual Education Delivery (DoVED).

Table 1: Non Degree Programmes

\begin{tabular}{|l|l|l|c|c|}
\hline S & Name of & \multicolumn{2}{|l|}{$\begin{array}{l}\text { Total number of Students } \\
\text { Programme }\end{array}$} & $\begin{array}{c}\text { \#students } \\
\text { admitted }\end{array}$ \\
\cline { 2 - 4 } & $1^{\text {st }}$ year & $2^{\text {nd }}$ year & \\
\hline 1. & $\begin{array}{l}\text { Certificate } \\
\text { in } \\
\text { Educational } \\
\text { Technology }\end{array}$ & 15 & - & 6 \\
\hline 2. & $\begin{array}{l}\text { Diploma in } \\
\text { Educational } \\
\text { Technology }\end{array}$ & 10 & 7 & - \\
\hline
\end{tabular}




\begin{tabular}{|l|l|l|l|l|}
\hline 3. & $\begin{array}{l}\text { Diploma in } \\
\text { ICT with } \\
\text { Education }\end{array}$ & 15 & 8 & - \\
\hline & & 40 & 15 & 6 \\
\hline
\end{tabular}

Table 2: Degree Programmes

\begin{tabular}{|c|c|c|c|c|c|}
\hline \multirow[t]{2}{*}{$\mathrm{S} / \mathrm{N}$} & \multirow[t]{2}{*}{$\begin{array}{l}\text { Name of } \\
\text { Programme }\end{array}$} & \multicolumn{3}{|c|}{$\begin{array}{l}\text { Total number of } \\
\text { Students admitted }\end{array}$} & \multirow{2}{*}{$\begin{array}{l}\text { \#Student } \\
\text { s } \\
\text { Graduate } \\
\text { d }\end{array}$} \\
\hline & & $\begin{array}{l}1^{\text {st }} \\
\text { year }\end{array}$ & $\begin{array}{l}2^{\text {nd }} \\
\text { year }\end{array}$ & $\begin{array}{l}3^{\text {rd }} \\
\text { year }\end{array}$ & \\
\hline 1. & $\begin{array}{l}\text { BSc. in Virtual } \\
\text { Education }\end{array}$ & 0 & 0 & 0 & 3 \\
\hline 2. & BSc. in MTA & 7 & 28 & 16 & 4 \\
\hline \multirow[t]{5}{*}{3.} & $\begin{array}{l}\text { BSc. in ICT- } \\
\text { MCD }\end{array}$ & 4 & 30 & 0 & 5 \\
\hline & & 11 & 58 & 16 & 12 \\
\hline & $\begin{array}{l}\text { BSc in ICT } \\
\text { with Education }\end{array}$ & \multicolumn{4}{|c|}{$\begin{array}{c}\text { To be offered in } 2015 / 16 \\
\text { academic year }\end{array}$} \\
\hline & $\begin{array}{l}\text { BSc. in Content } \\
\text { Eng. With IT }\end{array}$ & \multicolumn{4}{|c|}{$\begin{array}{c}\text { To be offered in } 2015 / 16 \\
\text { academic year }\end{array}$} \\
\hline & $\begin{array}{l}\text { Bachelor of } \\
\text { Educational } \\
\text { Technology }\end{array}$ & \multicolumn{4}{|c|}{$\begin{array}{c}\text { To be offered in } 2015 / 16 \\
\text { academic year }\end{array}$} \\
\hline
\end{tabular}

\subsection{Department of Content Engineering and Multimedia Technology}

DoCEMT has two sections namely; Content Engineering and Technology (CET) and Multimedia Technology and Animation (MTA). In addition DoCEMT offers a number of certificate, diploma, undergraduate and postgraduate programmes.

Table 3: Postgraduate Degree Programmes

\begin{tabular}{|l|l|l|}
\hline S/N & Name of Programme & Current Status \\
\hline 1. & $\begin{array}{l}\text { Master of Science in } \\
\text { Educational Technology }\end{array}$ & $\begin{array}{l}\text { Already approved to } \\
\text { be offered in } \\
2015 / 16 \text { academic } \\
\text { year }\end{array}$ \\
\hline 2. & $\begin{array}{l}\text { Master of Educational } \\
\text { Technology Leadership }\end{array}$ & $\begin{array}{l}\text { Already approved to } \\
\text { be offered in } \\
2015 / 16 \text { academic } \\
\text { year in }\end{array}$ \\
\hline 3. & $\begin{array}{l}\text { Postgraduate Diploma in } \\
\text { Educational Technology }\end{array}$ & $\begin{array}{l}\text { Already approved to } \\
\text { be offered in } \\
\text { year academic }\end{array}$ \\
\hline 4. & Postgraduate Diploma in & Already approved to \\
\hline
\end{tabular}

\begin{tabular}{|l|l|l|}
\hline & $\begin{array}{l}\text { School Technology } \\
\text { Integration, Coordination } \\
\text { and Leadership }\end{array}$ & $\begin{array}{l}\text { be offered in } \\
2015 / 16 \text { academic } \\
\text { year }\end{array}$ \\
\hline 5. & $\begin{array}{l}\text { Graduate Certificate in E- } \\
\text { Learning and Online } \\
\text { Teaching }\end{array}$ & $\begin{array}{l}\text { Already approved to } \\
\text { be offered in } \\
2015 / 16 \text { academic } \\
\text { year }\end{array}$ \\
\hline 6. & $\begin{array}{l}\text { Graduate Certificate in } \\
\text { School Technology } \\
\text { Integration, Coordination } \\
\text { and Leadership }\end{array}$ & $\begin{array}{l}\text { Already approved to } \\
\text { be offered in } \\
\text { 2015/16 academic } \\
\text { year }\end{array}$ \\
\hline
\end{tabular}

\subsubsection{Content Engineering and Technology \\ Section}

CET section deals with the issues pertaining to the use of content in computer-facilitated environments. This academic section is building capacity in content technology, content production, content management, content modeling, content conversion, and content use and repurposing. CET section is tending to bridge the gap between groups involved in the production of content (Broadcasting, instructional designers, Publishing and Editorial staff, Marketing, Sales, HR) and more technologically-oriented departments (such as IT and ICT) that put this content to use in web or other softwarebased environments, and requires an understanding of the issues and processes of both sides.

\subsubsection{Multimedia Technology and Animation Section}

MTA section is building capacity in content that uses a combination of different forms. This section contrasts with media that use only rudimentary computer displays such as text-only or traditional forms of printed or hand-produced material. Multimedia technology and animation includes a combination of text, audio, still images, animation, video, or interactivity content forms. Multimedia is usually recorded and played, displayed, or accessed by information content processing devices, such as computerized and electronic devices, but can also be part of a live performance.

\subsubsection{Proposed Programmes of study under \\ DoCEMT}

DoCEMT is proposed to offer non-degree namely, certificate in Multimedia Technology, Certificate in Web Technologies and Certificate in Content Technology, Diploma in Graphics and Web Technologies, Diploma in Broadcasting Engineering (E-Content) and Diploma in Multimedia Technology. The degree programmes are BSc. in Content Engineering and Information Technology with specialization in Broadcasting, Instruction Design and E-marketing, BSc. in ICT Mediated Content Development and BSc. in Multimedia Technology and Animation. Currently the Department is offering two degree programmes namely BSc. in ICT Mediated Content Development and BSc. in Multimedia Technology and Animation.

The proposed Postgraduate Degree programmes include Postgraduate Diploma in Multimedia Technology, Graduate Certificate in Multimedia Technology, MSc in Multimedia Technology and MSc in Animation Technology.

\subsubsection{Roles of DoCEMT}

DoCEMT concentrates on activities pertaining to virtual education delivery. Such activities include; Capacity building 
and provide competence to various UDOM staff in the area of Multimedia, Animation, Content Technology, Virtual reality, virtual world etc. Conduct Academic, Research and consultancy in the area of content Engineering and multimedia technology. Provide technical support and consultancy in the Department of Virtual Delivery. In additional, it Conduct seminars, and workshops in the areas of Content Engineering and Multimedia Technologies.

\subsection{Department of Virtual Educational Technologies and Applications}

DoVETA has two sections namely; Virtual Educational Technologies (VET) section, and Virtual Education Applications, Integration and Leadership (VEAIL) section. In addition, DoVETA is designed to offer a number of Certificate, Diploma, Undergraduate and Postgraduate programmes.

\subsubsection{Virtual Educational Technologies section}

VET section is building capacity in ethical practice of facilitating learning and improving performance by creating, using and managing appropriate technological processes and resources. The section is associated with e-teaching theory, instructional theory, learning theory and e-pedagogy.

\subsubsection{Virtual Education Applications, Integration and Leadership section}

The roles of VEAIL section is to improve teaching and learning through the application of educational technologies used in secondary schools, higher learning institutions, corporations, organizations, associations, governments' ministries, and foundations. The section is founded on the belief that leadership skills, technological integration and coordination competence is fundamental instrument to the successful utilization of technologies in educational settings and that access to the necessary knowledge should be universal, despite the barriers of distance, person physical limitations, and lifestyle. This section is intended to enhance the success for the current and future educational technology managers and leaders. Courses under this section will comprise leadership skills including planning with an emphasis on the integration of technology in teaching.

\subsubsection{Programmes of study under DoVETA}

Non-degree Programmes include Certificate in Educational Technology, Diploma in ICT with Education and Diploma in Educational Technology. All these programmes are currently running. The degree programmes are BSc. in ICT with Education (BSc. ICT-ED), BSc in E-Learning Technology with Education (BSc. ELTE) and Bachelor of Educational Technology. The first two programmes are science based programmes while Bachelor of Educational Technology is targeting a combination of different specializations. For postgraduate Degree Programmes the programmes include Graduate Certificate in Educational Technology, Integration and Leadership, Graduate Certificate in Online Teaching and Learning, Postgraduate Diploma in School Technology Integration, Coordination and Leadership, Postgraduate Diploma in Education Technology, Master of Educational Technology Leadership and Master of Science in Educational Technology.

\subsubsection{Roles of DoVETA in Virtual Education}

UDOM to have a foot print in the delivery of virtual education it will have to develop new systems and carry out research in all areas related to it. DoVETA apart from doing research and consultancy will conduct research in virtual learning platforms, learning management systems, security of delivery and content, ownership, marketing etc. DoVETA will concentrate on research activities that are aimed at bettering the Virtual Education delivery. The areas of concentration include; capacity building, conduct academic, research, consultancy, seminars and workshops in virtual educational technologies and applications. Provide technical support in the Department of Virtual Delivery such as Pedagogical Advisor, Instructional Design and E-Contents Quality assurance. Liaise with TCU [7] and other educational regulatory bodies to develop and publish guides for online learning. Liaise with section responsible for online Training to enhancing smooth educational delivery professionally. To provide pedagogic and technical support for the development of online assessment at the university, colleges, schools, department, sections and individual levels.

\subsection{Department of Virtual Education Delivery}

DoVED will offer virtual education degree programmes through different means namely, online, $\mathrm{CD}$, television and through establishment of educational centers. It is proposed to offer different Programmes in CIVE, CHSS, CoES, CoHS, CoNMS and CoED. DoVED has five sections namely; Colleges Virtual Education Coordination (CVEC), Virtual Library and Knowledge Management (VLKM), Content Development (CD) and Virtual Education Training and Administration (VETA).

\subsubsection{Colleges Virtual Education Coordination Subsection}

CVEC Subsection is responsible for receiving proposal from other colleges on programmes to be offered, proposing marketable programmes, and evaluating new programme. The roles of CVEC section include; in collaboration with College Principals, Deans and Heads of Departments identify a Program to be offered by various units within the university and coordinate curriculum development. Develop and maintain bi-directional communication with other sections and determine their needs. To study new and ongoing curriculum that needs new contents or revision. To liaise with UDOM academic units/departments /school /colleges/outsiders in the outsourcing courses from subject matter experts. Others include; forwarding the course outsourced to the Content Development section for further development process. Where applicable assist teaching various courses in DoCEMT and DoVETA. Coordinate programmes to be delivered, manage different programmes from different schools and manage e-schools. Coordinate research and Consultancy activities in the direction of determining new technologies for the implementation in DoVED.

\subsubsection{Content Development section}

Delivery of virtual education needs appropriately prepared and development of content for the various programmes to be offered. The role of this section shall be to coordinate and to oversee the preparation of content and to ensure appropriateness of such contents for the intended purpose. It shall in collaboration with the VETA to upload different contents for different programmes. The section shall also see if the developed multimedia content uses effectively and appropriately multimedia tools, studio, DVD/CD recorders, simulators and games to create virtual classroom environment. In addition, the section in collaboration with other departments in the school is overseeing other issues such as quality assurance and e-pedagogy. To perform these 
functions effectively, the section have divided into two subsections namely; Instructional Design and Multimedia Design.

\subsubsection{Instructional Design subsection}

The role of the Instructional Design subsection is to provide guidance and assistance to team members in the course development process (analysis, design, production, implementation and evaluation); in a manner that promotes sound instructional design principles. The instructional design subsection use production tools such as Dream weaver, Audacity, Articulate ${ }^{\circledR}$ and Adobe Flash ${ }^{\circledR}$ for course elements that members cannot develop, integrate all course elements including those developed at Virtual Education and those from schools, and provide input about overall, systematic course development strategy on an on-going basis. The key responsibilities of this subsection include liaising with CVEC section to identify deficiencies, if any, on the content from subject experts/colleges. Instructional design work, including guidance for course developers on instruction sequence, engaging the learner, interface design, formative and summative assessment, and similar matters and integration of course elements from multiple sources.

\subsubsection{Multimedia Subsection}

Multimedia subsection complements the multimedia and animations in content designed. This subsection includes; oversee the instruction in the operation to acquire, enhance, design, manage, output, and archive digital imaging, graph design and multimedia files. It serves as the Media developer for the SoVE. The subsection will need a multimedia laboratory. Also the subsection deals with arrangement of recording shifts/sessions for the instructors in coordination with the productions team and Recording of lectures.

\subsubsection{Virtual Library and Knowledge Management Section}

Virtual Education activities like many other academic activities at UDOM shall generate a lot of resources, content and new knowledge. These have to be properly stored, managed and controlled while ensuring that they are conveniently accessible all the time to the intended persons. This is meant to ensure that there is no unnecessary duplication of efforts at UDOM in its effort to excel in ICT and other fields. It should ensure continuity of developments made in different areas of specialty and research outputs irrespective of movement of staff. This is important since staff movement is inevitable for different reasons. It provides a section that shall facilitate sharing of information and knowledge and information access in the laboratory. The section shall management content; coordinate the storage and distribution to training section for distribution. In addition, the section will be responsible for management of virtual library within UDOM and beyond. The section will be custodian of all generated knowledge.

\subsubsection{Virtual Education Training and \\ Administration section}

VETA section provides a principle output for the DoVED. It is to deliver different programmes offered by the colleges using multimedia technologies where space and time shall not be a constraint. It shall also facilitate coordination and delivery of the same from other academic units of the university. The delivery shall involve registration, management and monitoring continuously the students. Therefore, a delivery platform has to be acquired, customized and developed to perform the perceived function. The same applies to the LMS. Therefore, administrative duties to support the training function are inevitable. Specific functions of this section include; Liaise with VLKM section to acquire the program to be offered. Coordination and conducting examinations on various centers and planning all matters related to examination. Provide direct students/Lecturers support of the LMS, assist with the maintenance of virtual education help desk documentation, and engage in student in learning activities. Other responsibilities include; maintaining records, coordination with E-Lecturers/Professors, and other related documentation.

\subsubsection{UDOM-LMS Planning and Resources Administration Section}

This section has mandate to develop courseware for different programmes that is appropriate for delivery using multimedia systems. These need a combination of different facilities. These include simulators, software, platforms, network systems, etc. Delivery also needs facilities that are networked, managed and monitored with a possibility of interactive function. Resources have to be protected and user (clients) continuously monitored. These will need an administrative unit to ensure that these functions are performed effectively and efficiently. The section is responsible for employing the latest ICT for networking, communicating and for establishing suitable network access and manage facilities.

\subsection{Challenges facing implementation of the School}

\subsubsection{Expectations by University management}

Some initial assumptions from colleagues were biased on offering programmes in virtual environment as a source of income to the University. With this assumption it was expected that the school will start offering programmes immediately. When events proved to be different the University management was disappointed. A committee to investigate the matter was constituted. Apart from other findings, the Committee observed that the school had made significant progress despite the existing challenges. It was emphasized that the envisaged SoVE is expected to offer programmes unique to UDOM, Tanzania and East Africa in general. It was observed further that, the modus operand of the school is based on practices adopted in developed countries including Australia, Malaysia, Canada and USA. It was recommended that to realize SoVE entailed a process. Such a process requires sagacity. The management needs to be close and provide support.

\subsubsection{Pressure from other Staff}

Most staff in the college perceived the implementation of the school differently. Some were of opinion that the school were been implemented based on best practice from other Universities like Center for Virtual Learning at the University of Dar es Salaam[8] and Open University of Tanzania[9]. This was sometimes pressurizing the Dean and staff in the School. Sometimes was making our work to be very difficult in educating them. However, it was decided to stick on the vision that virtual education professionals is like any other profession such as computer science and telecommunications engineering. The school after getting graduates for the first batch of students in virtual education and BSc in ICT MCD, it is realized that the success of virtual education delivery will entirely depend on virtual education professionals. 


\subsubsection{Shortage of Academic Staff}

Overall, throughout years, SoVE was experiencing acute shortage of academic staff in all areas. This necessitated for the school to use academic staff with background in computer science and telecommunications engineering. Also the school borrowed some academic staff from other universities/institutions such as Dar es Salaam Institute of Technology (DIT)[10] and University of Dar es Salaam [8]with knowledge in multimedia. To overcome the challenge the school established programmes whereby academic staff gained experience through teaching. Currently all courses in different programmes offered by SoVE are taught by internal staff.

\subsubsection{Need for incentives}

Some staff in various Colleges expressed the need for incentives to make content development successful. Royalty is an issue that cannot be overlooked since different staff will make content for use like publishing books. Ideally for any specific course to be offered online it requires participation of course authors, course reviewers (Instructive Design Specialist), course instructors (e-Instructors, e-Lecturers, eprofessors) and technical staff (HTML Designers, Graphical, Animator, Multimedia Designer, and Exercise Designers). Other participants include Colleges Virtual Education Coordinator, LMS Administrator, and Online Technical Advisory Team. All these groups of actors need incentives for their participation if not permanently employed for this specific activity. It was resolved that such issue can be included in the virtual education policy and regulations.

\subsubsection{Facilities, Connectivity and Technical staff availability}

At the beginning the University of Dodoma had no any basic equipment to facilitate operations including software, multimedia equipment and laboratory, audio laboratory, appropriate server, multimedia experts and instructional designers. Also the connectivity was very poor with a link capacity less than $128 \mathrm{kbps}$. The technology was WiMax and shared among of all staff at the University. Although, 2010 the fiber backbone infrastructures were installed by the Government. However, the challenges were vandalism among of local citizens where the network was laid. The challenge of vandalism was overcome by engaging indigenous people and educating them about optical fiber network. Most of them were in opinion that vandalizing and getting a portion of it can lead to earn some cash.

\subsubsection{The clients' awareness about the programmes}

The programmes offered by the SoVE for capacity building purpose are new to our clients including Teachers/Instructors at all levels of education in Tanzania as well as students, hence publicity is necessary.

\section{RECOMMENDATIONS AND CONCLUSION \\ 6.1 Recommendations regarding implementations of virtual school}

\subsubsection{School Organization Structure}

There is a need to look at the appropriate organization structure to enable operations of the School. This will enable the managers to spend more time to coordinate and strategize sectors issues to raise efficiency in fulfilling its duties and responsibilities. In various cases capacity building should be reflected. Contrary with most of the universities in developed countries which have opted to implementing the school/centers which are dedicated to offer online programmes only, it is proposed that building capacity with Department such as DoCEMT and DoVETA by offering different degree programmes and conducting researches can lead to sustainability of the School of Virtual Education.

\subsubsection{Implementation of policies, Regulations and Guidelines}

In the implementations of SoVE there is a need of ICT Policy and Procedures, Virtual Education Policy and its Regulations including virtual education guidelines. In the Virtual Education policy the issues to be considered include ICT infrastructure and connectivity, software and applications, course content development, course delivery, quality assurance, professional development and support, and change management. The guidelines should be used in conjunction with the Virtual Education Policy. The aim of guideline is to provide detailed steps and descriptions for the purpose of enriching the implementation of Virtual Education Policy. Without having such policies, regulations and guidelines, the school of virtual education can be hardly be implemented. However, during developing such policies, regulations and guidelines stockholders views should be respected.

\subsubsection{Procurement of Servers and Network Connectivity Equipment}

Procurement of servers and network connectivity are prerequisites for virtual education delivery. In addition it is recommended to procure modern switches for enhancement of metropolitan Area Network. To enhance reliability of services to be offered in virtual environment installation of mirror server is mandatory.

\subsubsection{Backup power supplies system}

It is recommended that back-up power system for content servers and switches be always operational for user to access content within quality of service and service level agreement (SLA). Also other means such as offline can be sorted out.

\subsubsection{Support by all Colleges/}

\section{Schools/Departments/units}

Online content development and initiation of new online programs for delivery requires full support by all levels of University/Institute/organization.

\subsubsection{Recruitment of staff with appropriate expertize}

There is a need to recruit staff with appropriate expertise in Virtual Education fields, for example content developers, epedagogy experts, Learning management Systems (LMS) experts, administrators etc.

\subsubsection{Funds for Content Development}

It is recommended that there is a need to sets aside funds for content development for Universities/ Colleges/ Schools/ Department/Organization which are venturing in virtual education to proceed with content development and trial run of programme.

\subsubsection{Establishment of Non Science based Programmes}

Most of programmes developed for capacity building were Science based programmes. For example of such programmes include BSc in Virtual Education, BSc in ICT Mediated Content Development and BSc in Multimedia Technology 
and Animation. These programmes are demanding background of mathematics and leave a lot of professionals without mathematical background. It is recommended that in developing school of virtual education whereby all actors can benefit from such technology there is a need to develop a programme which can be taken by all students from various areas of specialization. In our case Bachelor of Educational Technology degree programme is looking at developing expert with specialty in educational technology with other fields such as geography, Languages, History etc.

\subsection{Conclusion}

The decision to have SoVE was made by the University of Dodoma in November, 2008 with the primary function of delivering programs offered by different academic units at UDOM and beyond in virtual environment and build capacity in virtual education. Generally, it was assumed that this will be an easily task. However, at its infant stage, UDOM generally had low level of ICT with low capacity server, low capacity network infrastructure, poorly trained staff in this new innovation, lack of ICT policy and procedures, virtual education policy and its regulations, guidelines and limited internet connectivity (capacity). These are essential for operationalizing, development and delivery of programmes in virtual environment. To realize the school of virtual education, different initiatives were used. These include proposing the first structure with six sections which was in place in 2008. However, some other challenges were observed, which include lack of human resources to manage units, lack of expertise in virtual education, lack of incentive among of virtual education actors, lack of knowledge of virtual education among of academic and technical staff in other Colleges, etc. In 2009, three sections were proposed with all functions under 2008 structure imbedded in it. From 2009, a number of initiatives were in place which include establishment of different non degree, degree and postgraduate programmes. In 2010 the School started running BSc in Virtual Education and attracted only three students, however, this number were compensated by students from BED-ICT. Fewer students cause to split BSc in VE programme into three new programmes in 2011/2012 academic year for marketability point of view. In 2013, three departments were established. These include, Department of Virtual Delivery, Department of Content Engineering and Multimedia Technologies and Department of Virtual Education Technologies and Applications. Currently a total of twenty students graduated and 100 students are enrolled in different non degree and degree programmes. Generally to have vibrant SoVE there is a need to establish policy and procedures, infrastructures (i.e. connectivity, servers, CDs, software etc.) and capacity building among of the staff. Others include establishment of different programmes at different levels. However, since such innovative is new and there is a need of marketing different programmes, otherwise can lead to few students joining such programmes. Also the issue of incentive should be considered for content development activity and developing programmes which can build a staff without having background in science. Finally this paper is recommending the following; there is a need to look at the appropriate organization structure to enable operations of the School. Procurement of servers and network connectivity are prerequisites for virtual education delivery. It is recommended that back-up power system for content servers and switches be always operational for user to access content within quality of service and SLA. Online content development and initiation of new online programs for delivery requires full support by all levels of University/Institute/organization. There is a need to recruit staff with appropriate expertise in Virtual Education fields, for example content developers, e-pedagogy experts, LMS experts and administrators etc. It is recommended that there is a need to sets aside funds for content development for Universities/ Colleges/ Schools/ Department/Organization which are venturing in virtual education to proceed with content development and trial run of programme. It is recommended that in developing school of virtual education whereby all actors can benefit from such technology there is a need to develop a programme which can be taken by all students from various areas of specialization. The concluding remarks are that the implementations of the School of Virtual Education are processes which need all actors to be patient. It needs a lot of thinking and reflections. It needs support from management, academic staff, technical staff and students.

\section{ACKNOWLEDGEMENTS}

The Author would like to acknowledge the contribution from the following academic staff Dr. L. J. Mselle the Second Dean School of Virtual Education for his contribution. Prof. N. H. Mvungi, the first Principal, College of Informatics and Virtual Education, University of Dodoma and the first Principal, College of Information and Communication Technologies, University of Dar es Salaam, Tanzania. Other includes Prof. A. M. Mvuma, the second Principal of College of Informatics and Virtual Education, University of Dodoma. In addition, special thanks should go to Ms Rukia Mwifunyi, Mr. Vumilia Ngeze and Mr. Deo Shao, Head of Content Engineering and Multimedia Technology, Head of Department of Virtual Education Delivery and Head of Department of Virtual Educational Technologies and Applications respectively and all staff in the School of Virtual Education for their contribution for success of SoVE.

\section{REFERENCES}

[1] The University of Dodoma, www.udom.ac.tz, accessed, $30 / 12 / 2014$.

[2] Dodoma Municipal, www.dodoma.go.tz, accessed, $30 / 12 / 2014$.

[3] Universities Act No. 7 of 2005, http://www.wipo.int/wipolex/en/details.jsp, accessed, $16 / 02 / 2015$

[4] http://www.juliusnyerere.info/ accessed, 30/12/2014

[5] The University of Dodoma ICT Policy and Procedures, 2011, available at www.udom.ac.tz, accessed, $30 / 12 / 2014$

[6] The University of Dodoma Virtual Education Policy and Regulations, 2013, unpublished document

[7] Tanzania Commission for Universities, http://www.tcu.go.tz, accessed, 16/02/2015

[8] The University of Dar es Salaam, www.udsm.ac.tz, accessed, 16/02/2015.

[9] The Open University of Tanzania, www.udsm.ac.tz, accessed, 16/02/2015.

[10] The Dar es Salaam, www.dit.ac.tz, accessed, 16/02/2015. 